\title{
The building complex of the region in the aspect of implementing the main directions of the Strategy for the Development of the Housing Sector
}

\author{
Vitaly Peshkov ${ }^{1, *}$ \\ ${ }^{1}$ Irkutsk National Research Technical University, 664074, Irkutsk, Lermontova str., 83, Russia
}

\begin{abstract}
The priority task of the social and economic development of the Russian Federation is providing the population with housing. The strategy for the Development of the Housing Sector in the Russian Federation for the period until 2025 is aimed at improving the living conditions of the population. As follows from this Strategy, "Each family must be able to improve its housing conditions in various ways." Considering the urban environment, the Strategy assumes that "the transition from the construction of square meters to housing in a comfortable urban environment" and "the development and implementation of standards for the integrated development of territories." The article systemically analyzes the basic directions of improving various aspects of building houses in the city environment in the aspect of increasing the demand and offer of the finished building products. The rating of the Irkutsk developers is made on the volume of housing introduced in 2016, as well as the mission, the company's strategy, and the strategies of its subdivisions. The corresponding conclusions are also made.
\end{abstract}

Providing the population with housing remains a priority task for the social and economic development of the Russian Federation.

The Russian housing development strategy for the period until 2025 (the Ministry of Construction of Russia, AIZHK, the Center for Strategic Research) is aimed at improving the living conditions of the population. As follows from the aforementioned Strategy, "Each family should be able to improve their housing conditions in various ways (buying a house in a property or renting, buying a ready home or at the stage of construction, construction from own funds). The form of improving housing conditions should be selected, which most fully reflects the needs of the family, taking into account its life cycle. The state should ensure such conditions under which the rights of all citizens and market participants are protected, all operating mechanisms are transparent, a balance of interests of all interested parties is ensured" [2].

From the analysis of the Strategy, we can say that it describes in some detail the main directions for addressing the research aspects in the construction of housing in the urban

*Corresponding author: pvv@istu.edu 
environment. These directions have been thoroughly studied before by Russian and foreign scientists [3].

Considering the urban environment, the Strategy assumes: "the transition from the construction of square meters to housing in a comfortable urban environment" and "the development and implementation of standards for the integrated development of territories." When developing measures to improve the directions, approaches, mechanisms, tools in the construction sector, the Strategy points out at: (a) increasing the housing security of the population (important are not only square meters, but also the number of rooms in the housing); (b) reducing administrative barriers in construction; (c) increasing transparency of the construction industry; (d) creating an effective mechanism for guaranteeing the rights of citizens participating in shared construction; (e) creating a system for financing construction through banking mechanisms without direct involvement of the population's funds; (f) supporting the construction of infrastructure from the federal budget in the implementation of priority housing projects and development programs for built-up areas; (g) stimulating the modernization of the construction industry and improving the quality of industrial housing construction by gradually banning the use of obsolete technologies and stimulating the use of new technologies. Finally, approaches to the solution of the land issue for the purposes of housing construction have been proposed. The Strategy notes and focuses on two main areas and approaches, namely "the transition from the expansion of cities to the efficient use of built-up areas and empty areas within urban boundaries" and "the integrated development of industrial zones and development of built-up areas associated with accelerating the retirement of the existing housing stock" [1].

A system analysis of the main directions of improving various aspects of housing construction in the urban environment for increasing the demand and supply of the finished construction products predetermines the corresponding requirements for the main participants in the process of housing construction, practically to the entire construction complex of the region and, first of all, to construction organizations. The implementation of these provisions for the main part of construction organizations will require revision and processing of both organizational and economic mechanisms, as well as organizational and technological regulations and decisions, which would have a significant impact on all areas of its activities. To the greatest extent, this will have an impact on the construction organizations of the regions, including the Irkutsk region. Tables 1, 2, and 3 provide data on the volume of housing being built in 2016 by the construction companies in the Irkutsk region.

Table 1. Rating of developers in Irkutsk by the volume of housing introduced in 2016.

\begin{tabular}{|c|l|r|}
\hline No & \multicolumn{1}{|c|}{ Компания } & $\begin{array}{c}\text { Введено, } \\
\text { кв.м. }\end{array}$ \\
\hline 1 & GK Domstroy & 71110 \\
\hline 2 & Nord-Vest & 49541 \\
\hline 3 & GK VostSibStroy & 37907 \\
\hline 4 & Tsentralnyy park & 35928 \\
\hline 5 & GK Instroytekh & 24293 \\
\hline
\end{tabular}

\begin{tabular}{|c|l|r|}
\hline 6 & $\begin{array}{l}\text { AZGI (Novyy gorod, } \\
\text { Vostok Tsentr Irkutsk, } \\
\text { Sibaviastroy) }\end{array}$ & 23423 \\
\hline 7 & Monopoliya+ & 19963 \\
\hline 8 & Sibstroykomplekt & 19157 \\
\hline 9 & Rodnyye berega & 18607 \\
\hline 10 & Avitsenna-Stroy & 18529 \\
\hline 11 & Mairta & 17384 \\
\hline 12 & Region Sibiri & 15931 \\
\hline
\end{tabular}




\begin{tabular}{|c|l|r|}
\hline 13 & UKS g. Irkutska & 15226 \\
\hline 14 & Stroyrekonstruktsiya & 13768 \\
\hline 15 & Grand-Stroy & 13135 \\
\hline 16 & Pchely & 12709 \\
\hline 17 & Tanar & 12569 \\
\hline 18 & Vostok Tsentr Irkutsk & 12201 \\
\hline 19 & INTS SO RAN & 11512 \\
\hline 20 & GK ParapetStroy & 11220 \\
\hline 21 & SibirEnergoTreyd & $10080^{*}$ \\
\hline 22 & Delovyye investitsii & 8827 \\
\hline 23 & Vysota & 8768 \\
\hline 24 & GK Trud & 8466 \\
\hline
\end{tabular}

\begin{tabular}{|c|l|r|}
\hline 25 & Drimstroy & 7543 \\
\hline 26 & MobiKlin & 7276 \\
\hline 27 & Zheldoripoteka & 7140 \\
\hline 28 & VSSK Vostok & 6969 \\
\hline 29 & Eko+ & 6197 \\
\hline 30 & IrkutskGorRemStroy & 6185 \\
\hline 31 & BaykalStroyInvest & 5914 \\
\hline 32 & Profit & 4609 \\
\hline 33 & Viskhod FSK & 4224 \\
\hline 34 & Ofisstroy & 3004 \\
\hline 35 & GK SibEnergiRemStroi & 1574 \\
\hline
\end{tabular}

As follows from the given data the basic building organizations in housing construction are: GK Domstroy, Nord-Vest, GK VostSibStroy, Tsentralnyy park, GK Instroytekh, AZGI (Novyy gorod, Vostok Tsentr Irkutsk, Sibaviastroy), Monopoliya+, Sibstroykomplekt, Rodnyye berega, Avitsenna-Stroy, Mairta, Region Sibiri, UKS g. Irkutska, Stroyrekonstruktsiya, Grand-Stroy, Pchely, Tanar. In terms of the volume of housing, they cannot be called as the known companies in housing construction. Although it should be noted that many of them work in the market for quite a long time: GK Domstroy, GK VostSibStroy, UKS g. Irkutska, Tanar, Vostok Tsentr Irkutsk.

Figure 2 shows the mission, the company's strategy, and the strategies of its divisions. The mission is defined as "We work in order to be the best in construction and meet all the needs of buyers through high quality." The company's strategic goal is to ensure the company's competitive advantage. By business units, you can list their strategic objectives in the following manner: (a) to increase the company's share in the market; (b) to optimize transaction costs; (c) to increase the range and number of apartments; (d) to master new types of planning; (e) to strengthen the control over the quality of building materials; (f) to modernize production; $(\mathrm{g})$ to create a line of consultations for buyers; and $(\mathrm{h})$ to expand the list of services to customers.

The map of the strategic goals of this organization is shown in Figure 2. As follows from the map of strategic goals, the company refers to the following target indicators: market share in \% (increasing the company's share in the market); volume of sales; achieving profitability (improving the profitability of the company); maintaining the level of average trade markup\%; reducing the waste to a level no higher than 5\% ( to strengthen control over the quality of materials, internal processes); to provide buyers of services (legal, economic purpose) (expand the list of existing services to customers); opening the company's website online consultation (a consultation line for buyers).

Thus, it can be stated that implementing the directions of the "Strategy for the Development of the Housing Sector of the Russian Federation for the period until 2025" will require a significant adjustment of the goals, objectives, and strategies for developing enterprises in the construction industry. A set of measures is needed to support the construction organizations of the region. 


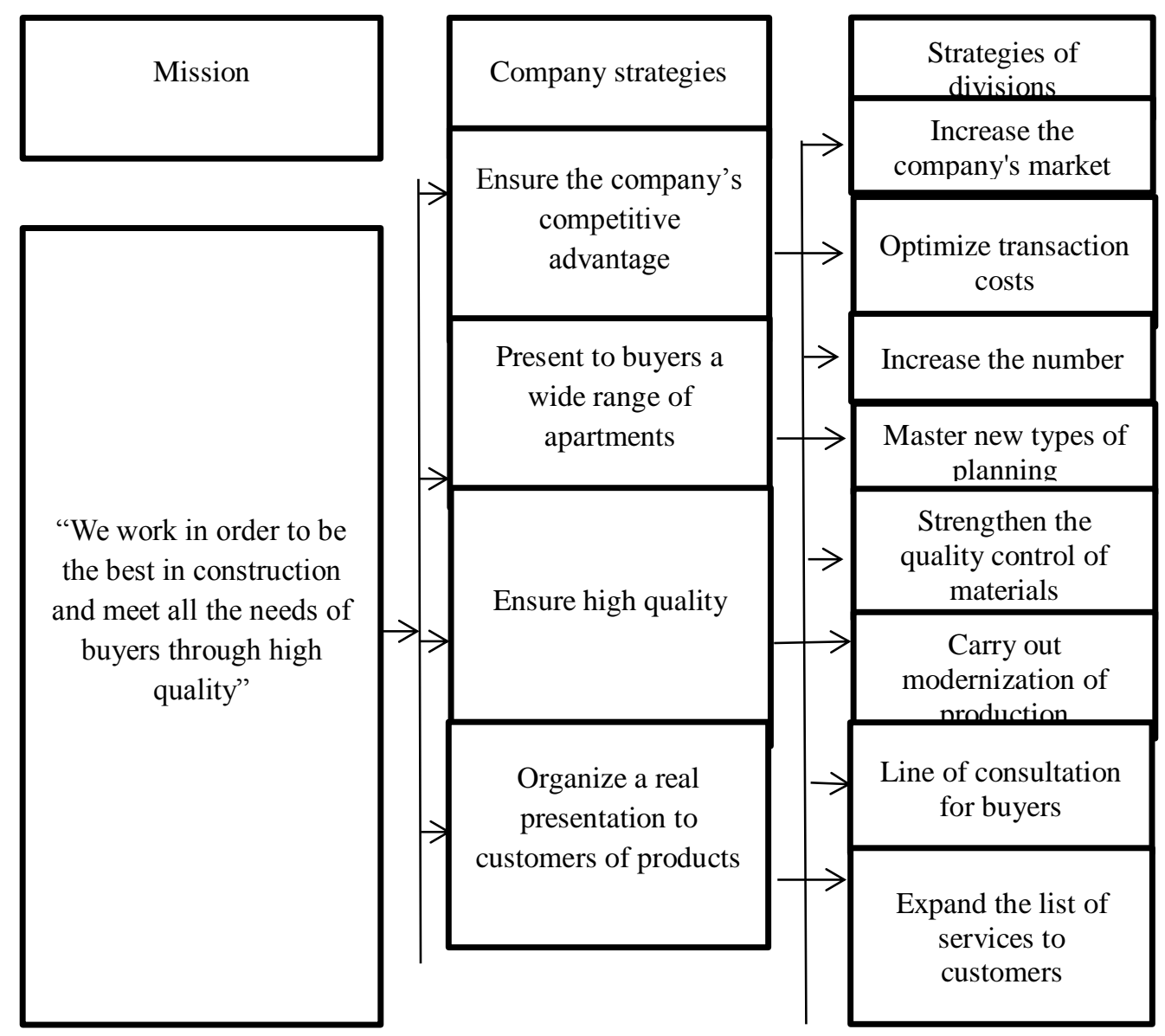

Fig. 1. Strategic tasks. 


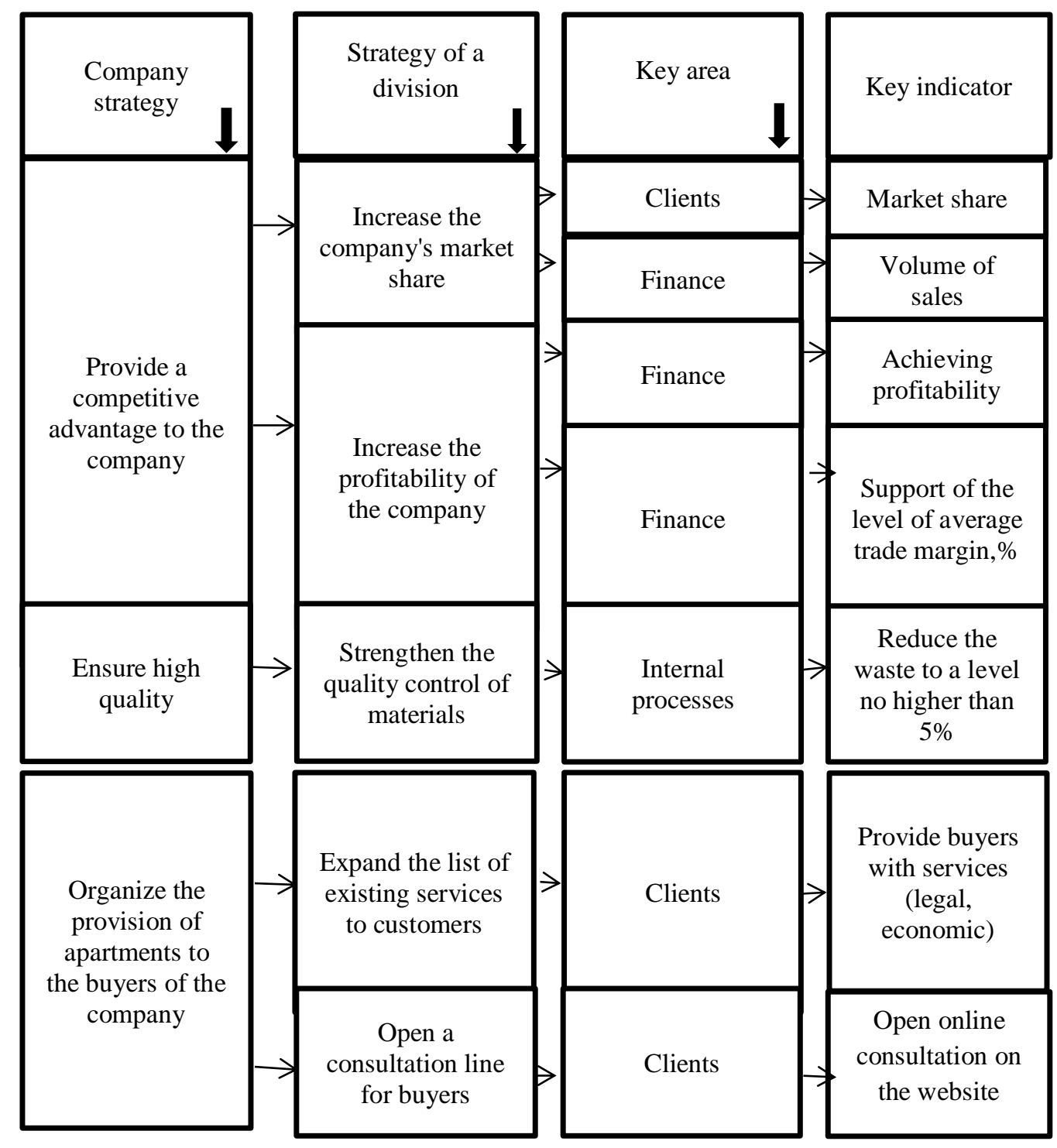

Fig. 2. The map of strategic goals.

\section{References}

1. Government of Russia, Strategy for the Development of the Housing sector of the Russian Federation for the period up to 2025 (http://www.minstroyrf.ru/docs/15909/, Moscow)

2. N. Yu. Yaskova, Proceedings of Universities. Investment. Construction. Real Estate, 8, 1(24), 133-142 (2018). 
3. N. Yu. Yaskova, Real Estate: Economics, Management, 3, 35-38 (2017).

4. M. V. Matveeva, A. P. Chuprov, Fundamental Research, 12-3, 673-677 (2016).

5. M. V. Matveeva, Targeted focusing as a tool for implementing national development priorities (Irkutsk State Technical University, Irkutsk, 2013) 